\title{
Role for International Tobacco Control in Peacebuilding?
}

\author{
Harvey Skinner, ${ }^{1}$ Jack Mandel ${ }^{2}$ and Catharine Whiteside ${ }^{3}$ \\ ${ }^{1}$ Dean, Faculty of Health, York University and Chair of CISEPO Board of Directors, Canada \\ 2 Director, Dalla Lana School of Public Health, University of Toronto, Canada \\ ${ }^{3}$ Dean of Medicine and Vice Provost Relations with Health Care Institutions, University of Toronto, Canada
}

The health and economic consequences of tobacco use transcend international boundaries. In response to this global epidemic, international tobacco control (ITC) has engaged a diverse international network of researchers, health practitioners and policy makers from over 160 countries who are supporting the Framework Convention on Tobacco Control (FCTC), the first of its kind for the World Health Organization. ${ }^{1}$ The FCTC was adopted by the World Health Assembly on 21 May 2003 and made into force on 27 February 2005. This evidence-based treaty is a landmark for global public health in responding to globalisation of the tobacco pandemic. It provides policy and legal measures for international health cooperation.

However, is there another role that the ITC community can play in using its global reach to foster cooperation, especially in regions of conflict? The experiences of the Canada International Scientific Exchange Program or CISEPO ${ }^{2}$ provide valuable insights for answering this question.

CISEPO is an international cooperation network of health professionals, academics and students coming from many different disciplines but with a shared commitment to peacebuilding (Skinner, Abdeen, Abdeen, Aber, Al-Masri et al., 2005). For over a decade, Israeli, Jordanian and Palestinian colleagues have worked together through CISEPO's ongoing professional engagement across religious, political and cultural borders. CISEPO is creating opportunities for cooperation in the Middle East. Some examples include:

- Screening and habilitation of almost 200,000 newborns for hearing loss - a major health concern in the region (Skinner et al., 2005),

- Joint research by Palestinian and Israeli scientists on the genetic basis of hereditary sensorineural hearing loss (SNHL) - the most common form of congenital hearing impairment (Shahin, Walsh, Sobe, Lynch, King et al., 2002).
- Joint continuing education and professional development for more than 3500 Arab and Israeli professionals meeting face-to-face in the Middle East and through video-conferencing (Noyek, Skinner, Davis, Clark, Sriharan et al., 2005).

- Engagement of Bedouin, Palestinian and Israeli youth in community health promotion projects including smoking prevention (Bader, Wanono, Hamden, \& Skinner, 2007).

- Research on the dynamics of cross-border cooperation, including: (a) what attracted Arab and Israeli participants to the project on early detection of newborn hearing loss (b) the challenges they faced and (c) lessons learned for guiding cross-border health initiatives (Skinner \& Sriharan, 2007).

The article 'Water Pipe Smoking: Effects, Attitudes and Directions' by Watad and colleagues, published in this issue of the Journal of Smoking Cessation, was composed by Israeli, Palestinian, Jordanian and North American authors affiliated with CISEPO. The authors address how water pipe (WP) smoking is prevalent in the Middle East and beyond - emerging as a major international public health issue. This demonstration of Arab and Israeli cooperation is an important example of how joint interest in health can overcome borders and build cooperation. We propose that such unique cooperation should be emphasised on the international stage.

The CISEPO bi-level model integrates project specific goals for improving health services and outcomes (e.g., tobacco control), with meta-level goals for building mutual understanding, respect and cooperation through knowledge exchange (Skinner et al., 2005; Skinner \& Sriharan, 2007). This model guides the setting of priority goals and specific actions for using Health as a Bridge for Peace (HBP). Initially advanced in 1984 by the Pan American Health Organization, ${ }^{3}$ HBP is a multidimensional framework which supports health workers in delivering health programs in conflict 
and postconflict situations and at the same time contributes to peace-building (Santa Barbara \& MacQueen, 2004). CISEPO believes that sharing health expertise, techniques and knowledge can be a bridge to peace. ${ }^{4}$

We invite dialogue about roles that knowledge networks, such as the ITC, can play in contributing to health security, conflict resolution and global public health promotion. For example, the international and regional conferences of the Society for Research on Nicotine and Tobacco (www.srnt.org) provide an excellent forum for initiating discussion and planning for Health as a Bridge for Peace tobacco control related initiatives. Colleagues at our Canadian institutions and CISEPO are eager to help.

In conclusion, the health sector provides a powerful venue for building international cooperation networks. This challenge was underscored almost 30 years ago by the World Health Organization assembly resolution: ${ }^{5}$ 'The role of physicians and other health workers in the preservation and promotion of peace is the most significant factor for the attainment of health for all'.

\section{Endnotes}

1 World Health Organization Framework Convention on Tobacco Control. Available at http://www.who.int/fctc/en/

2 Canada International Scientific Exchange Program (CISEPO) is based in Toronto at Mount Sinai Hospital in the Peter A. Silverman Centre for International Health; at the Dalla Lana School of Public Health, University of Toronto; and at the Faculty of Health, York University. In the Middle East, CISEPO is led by its Israeli, Palestinian and Jordanian regional directors, and in the United States by the President of American CISEPO. Available at www.cisepo.ca

3 World Health Organization, Health as a Bridge for Peace (HBP). Available at http://www.who.int/hac/techguidance/ hbp/en/index.html

4 Blumenthal, S., Safdi, S., \& Hoffman, B. Peace through health: A mapping of cooperative health program in
Palestine and Israel: A Report of the Palestine / Israel Health Initiative (PIHI). A Center for the Study of the Presidency Project on 'Advancing Trust and Reconciliation among Palestinian and Israelis'. Available at http:// www.thepresidency.org/Programs/health_and_medicine_ publications.php

5 World Health Organization 1981, Resolution 34:48.

\section{References}

Bader, R., Wanono, R., Hamden, S., \& Skinner, H.A. (2007). Global youth voices: Engaging Bedouin youth in health promotion in the Middle East. Canadian Journal of Public Health, 98, 21-25. Expanded results are at the Global Youth Voices website: http://www.globalyouthvoices.org/ middleeast/greetings-en.htmlSanta Barbara, J., \& MacQueen, G. (2004). Peace through health: key concepts. Lancet, 364, 384-386.

Noyek, A.M., Skinner, H.A., Davis, D., Clark, I., Sriharan, A., \& Chalin, C.G. (2005). Building bridges of understanding through continuing education and professional development of Arabs and Israelis. Journal of Continuing Education in the Health Professions, 25, 198-209.

Shahin, H., Walsh, T., Sobe, T., Lynch, E., King, M.-C, Avraham, K.B., et al. (2002). Genetics of congenital deafness in the Palestinian population: Multiple connexin 26 alleles with shared origins in the Middle East. Human Genetics, 110, 284-289.

Skinner, H.A., Abdeen, Z., Abdeen, H., Aber, P., Al-Masri, M., Attias, J., et al. (2005). Promoting Arab and Israeli cooperation: A model for peacebuilding through health initiatives. Lancet, 365, 1274-1277.

Skinner, H.A., \& Sriharan, A. (2007). Building cooperation through health initiatives: An Arab and Israeli case study. Conflict and Health, 1, 8. Available at http://www.conflict andhealth.com/content/1/1/8 